Hepatitis A: seroprevalence

and associated factors among

schoolchildren of São Luís (MA),

Brazil

\section{Hepatite A: soroprevalência e fatores associados em escolares de São Luís (MA), Brasil}

\section{Márcia Andréa Costa Gomes}

Adalgisa de Sousa Paiva Ferreira

Antonio Augusto Moura da Silva

Eliane Rabelo de Souza

School of Medicine - Federal University of Maranhão.

Trabalho realizado (informar instituição).

Conflito de interesse: (nada a declarar).

Financiamento: (informar financiamento)

Correspondência: Márcia Andréa Costa Gomes. Rua dos Bicudos, lote 1, Quadra 10, Ed. Toulon

Apto - 704, Renascença II - São Luís, MA CEP 65075-090. E-mail: marcia.med@elo.com.br

\section{Abstract}

Objectives: To estimate the prevalence of antibodies to hepatitis A virus (antiVHAIgG) in children aged 7-14 years from public and private schools, and to identify demographic, socioeconomic and sanitation factors associated with the prevalence of antiVHA-IgG. Methods: Seroepidemiological study for the detection of IgG antiVHA. It was conducted from April 2002 to April 2004 with 462 elementary school students from São Luis, ranging from 7 to 14 -years of age. Thirty schools randomly selected took part in the study, with a probability proportional to the number of students enrolled; 23 schools were public and 7 were private. Data was obtained through a structured questionnaire. In order to identify the variables independently associated with IgG antiVHA, the Poisson multiple regression analysis was performed, estimating the adjusted PRs and their $95 \%$ confidence intervals. The variables associated with the prevalence of hepatitis A with $\mathrm{p}<0$ were the only ones that remained in the final model. The level of significance of $0.05(\alpha=0.05)$ was adopted. Results: The prevalence of antiVHA-IgG was $64 \%, 71.5 \%$ in public and $36.5 \%$ in private schools. After multivariate analysis, age 11 to 14 years, more than one person per bedroom, and less than two bathrooms per household were associated with a higher prevalence of antiVHA-IgG. Higher parental education was associated with lower prevalence of antiVHA-IgG. Conclusions: Hepatitis A is endemic among schoolchildren in São Luís. The prevalence rate was similar to those found in other regions of the country with similar socio-economic and health conditions. Factors historically associated with a higher prevalence of hepatitis A were also identified in this population.

Keywords: Hepatitis A. Prevalence. AntiVHAIgG. Schoolchildren. Seroepidemiologic survey. 


\section{Resumo}

Objetivos: Estimar a prevalência de anticorpos contra o vírus da hepatite A (antiVHA-IgG) em escolares de 7 a 14 anos de escolas públicas e privadas e identificar fatores demográficos, socioeconômicos e sanitários associados à prevalência de antiVHA-IgG. Métodos: Estudo soroepidemiológico para detecção de antiVHA-IgG, de abril de 2002 a abril de 2004, em 462 escolares de São Luís, com idades compreendidas entre 7 e 14 anos, do ensino fundamental. Participaram 30 escolas aleatoriamente selecionadas, com probabilidade proporcional ao número de alunos matriculados, sendo 23 públicas e 7 privadas. Os dados foram obtidos por meio de questionário estruturado. Para se identificar variáveis independentemente associadas à prevalência do antiVHA-IgG, foi realizada análise de regressão de Poisson múltipla, sendo estimadas as RPs ajustadas e respectivos intervalos de confiança de $95 \%$. Somente permaneceram no modelo final aquelas variáveis associadas com a prevalência da hepatite $A$ com $p<0,10$. Foi adotado o nível de significância de 0,05 ( $\alpha=0,05)$. Resultados: A prevalência de antiVHA-IgG foi de $64 \%$, sendo de $71,5 \%$ nas escolas públicas e de $36,5 \%$ nas privadas. Após análise multivariável, idade de 11 a 14 anos, mais de uma pessoa por dormitório e menos de dois banheiros por domicílio foi associada a maiores prevalências de antiVHA-IgG. Maior escolaridade dos pais esteve associada à menor prevalência de antiVHA-IgG. Conclusões: A hepatite A é endêmica nos escolares de São Luís, com taxa de prevalência semelhante àquela encontrada em outras regiões do país com condições socioeconômicas e sanitárias similares. Fatores historicamente associados à maior prevalência da hepatite A foram também identificados nesta população.

Palavras-chave: Hepatite A. Prevalência. AntiVHA-IgG. Escolares. Inquérito soroepidemiológico.

\section{Introduction}

Hepatitis A Virus (HAV) is the most common cause of acute viral hepatitis in the world ${ }^{1}$. It is usually a self-limiting disease that resolves spontaneously in most infected individuals ${ }^{2}$. In general, it is an asymptomatic disease in children but it can cause severe symptomatology in young people and mainly in older adults, and it may lead to fulminant hepatitis at a rate of $1.8 \%$ in individuals over 50 years old ${ }^{3,4}$. Despite being a rare condition in Brazil, 10 to $20 \%$ of pediatric liver transplants are performed in patients with acute liver failure caused by Hepatitis A virus (HAV) ${ }^{5}$.

The transmission is mainly via fecaloral route, and the levels of hygiene and sanitary conditions are the most important influences on this disease incidence. Thus, the infection evolves in parallel with the socio-economic transformations of certain regions ${ }^{6,7}$.

The prevalence of IgG anti-HAV is used to define high, intermediate and low endemicity areas. High endemicity is found in countries with poor sanitary conditions and social disadvantage, and the infection occurs mainly in young children. Intermediate rates are typically found in countries with economies in transition in which children may not be infected, which makes adults more susceptible to this disease, and lastly, low or very low rates are found in industrialized countries where the disease is restricted to risk groups and outbreaks ${ }^{8,9}$.

A multicenter study conducted in South America, by Tapia-Conyer and 10 contributors, including six countries (Mexico, Chile, Brazil, Dominican Republic, Venezuela and Argentina), involving 12,085 individuals from 10 to 40 years old, suggests a pattern of change from high to intermediate endemicity in these regions.

In Brazil, the prevalence rates of hepatitis A are still precarious. Most studies were performed on samples that were not representative of the population. Available studies indicate different patterns of endemicity, which reach up to $95 \%$ in the North, 
Northeast and Central-West regions. In the South and Southeast regions prevalence tend to be lower ${ }^{8,11,12,13}$.

The goal of this study was to estimate the prevalence of IgG anti-HAV in students aged from 7 to 14 years old in São Luís and to identify factors associated with the prevalence of this infection.

\section{Methods}

São Luis, capital of Maranhão, according to latest estimates from IBGE ${ }^{14}$, has about 986,826 inhabitants. In 2003, the year of data collection for this study, there were 196,957 students enrolled in elementary school (1st through 8th grades) in 408 public (155,365 students) and private (41,592 students) schools, according to data provided by the records of the Maranhão State and City of São Luís Education Departments ${ }^{15}$.

In order to estimate the prevalence of antibodies against hepatitis A virus, the sample size was estimated at 480 individuals, taking into account an estimated prevalence of $70 \%$, absolute precision of $5 \%$ and confidence level of $95 \%$.

Cluster sampling was used in three stages, with the division of schools into public and private. In the first stage, 30 schools were drawn by systematic sampling and the probability was proportional to the number of enrolled students. Then, we obtained lists of the number of classrooms per grade and the number of students attending classes regularly in these classrooms. Through a simple random sample, one classroom was drawn from each grade in the second stage, and two students were drawn from each classroom in the third stage (two students from each age), with a total of 16 students per school.

From meetings with leaders, the following data related to identification and sociodemographic characteristics were recorded on a standardized questionnaire: the individual and the school's name, school type (public or private), gender, age, address, number of household members, number of rooms, number of people sleeping to- gether in the same room, family income, educational level of parents or guardians, availability of piped water supply, presence of sewage and the existence and number of bathrooms in the house.

We continued the procedures by collecting $5 \mathrm{ml}$ blood samples, which were sent to the Central Laboratory of Public Health LACEN of the Oswaldo Cruz Institute, where laboratory tests were performed. All blood samples were centrifuged and stored in a freezer at $-20^{\circ} \mathrm{C}$. Later these samples were further processed. The IgG anti-HAV was tested by the method of enzyme immunoassay (ELISA) with microparticle. The reagent used came from Abbott Laboratories.

We included those students whose guardians signed an informed consent form. We excluded those students who refused blood collection (seven students at private schools and one student at public schools), those who were absent on the day of collection (two) and those with problems filling out the forms or identification of the material collected (eight). The final sample consisted of 462 students.

The study was approved by the Ethics Committee of President Dutra University Hospital of the Federal University of Maranhão under the number 093/REIT./2003.

Prevalence rates were represented by percentages with their respective $95 \%$ confidence intervals $(95 \% \mathrm{CI})$. In order to identify associations in unadjusted analysis, gross prevalence ratios (PR) and their respective 95\% confidence intervals were estimated. In order to identify variables independently associated with prevalence, the Poisson multiple regression analysis was performed, which estimated the adjusted PRs and their 95\% confidence intervals. For the variable selection, stepwise regression through backward elimination method was used. Those variables associated with the prevalence of hepatitis A with $\mathrm{p}<0.10$ were the only ones that remained in the final model. We adopted a significance level of $0.05(=0.05)$. Stata, version 11software was used for the statistical analysis. Since this was a complex sampling design, in all statistical analysis, 
we used the svy commands, and corrected the standard errors taking into account the previous school type (public and private ) stratification of the sample and primary sampling unit (the school).

\section{Results}

Two hundred and forty three (53\%) of the 462 children studied were male. The age ranged from 7 to 14 years old, with mean and standard deviation of $11 \pm 2$. Three hundred and fifty-eight $(77 \%)$ were students who attend public schools and 104 (23\%) were from private schools. The rate of seroprevalence of IgG anti-HAV was $64 \%$ (IC $95 \% 60 \%$ to $68 \%$ ), and $71.5 \%$ (IC $95 \% 69 \%$ to $74 \%$ ) in public schools and $36.5 \%(95 \% 32 \%$ to $41 \%$ ) in private schools.

In unadjusted analysis, gender ( $\mathrm{p}=$ $0.106)$, number of household members $(p=0.630)$ and number of rooms per house $(\mathrm{p}=0.060)$ were not associated with the prevalence of IgG anti-HAV. Schoolchildren aged from 11 to 12 years old $(\mathrm{PR}=1.39)$ and from 13 to 14 years old $(\mathrm{PR}=1.46)$ had higher prevalence of IgG anti-HAV. Family income of $4(\mathrm{PR}=0.65)$ or more than four minimum wages $(\mathrm{PR}=0.26)$ and having parents with incomplete secondary education $(\mathrm{PR}=$ $0.59)$, completed high school $(\mathrm{PR}=0.71$ ) or higher education $(\mathrm{PR}=0.19)$ were associated with lower prevalence of IgG anti-HAV. More than one person per bedroom $(\mathrm{PR}=1.90)$, not having piped water supply at home $(\mathrm{PR}=1.32)$ and less than two bathrooms per house $(\mathrm{OR}=2.06)$ were associated with higher prevalence of IgG anti-HAV (Table 1).

In multivariate analysis, ages from 11to 12 years old ( $\mathrm{PR}=1.36)$, from 13to 14 years old $(\mathrm{PR}=1.40)$, having more than one person per bedroom $(\mathrm{PR}=1.55)$ and less than two bathrooms per house $(\mathrm{PR}=1.36$ ) were independently associated with higher prevalence of IgG anti-HAV. Having parents with incomplete high school $(\mathrm{PR}=0.68)$ or higher education $(\mathrm{PR}=0.26$ ) were independently associated with lower prevalence of IgG anti-HAV (Table 2).

\section{Discussion}

The high prevalence of IgG antibodies against hepatitis A virus identified in São Luís schools (64\%) characterizes the city as an area of high endemicity. The results of the National Survey of Viral Hepatitis Prevalence in Brazil showed prevalence data for the Northeast, Central-west and Federal District to the ages from 5 to 9 years old and from 10 to 19 years old, $41 \%$ and $57 \%, 32 \%$ and $56 \%$ and $33 \%$ and $65 \%$ respectively ${ }^{7}$. Comparing the data from this study with the National Survey, it seems that São Luís is among the areas with the highest prevalence of hepatitis A among school children.

This study also showed a higher prevalence of IgG anti-HAV students in public schools $(71.5 \%)$ than in private schools (36.5\%), which reflects important differences in living conditions of these individuals, despite the fact they live in the same city. Other studies have also shown important socioeconomic differences in epidemiological patterns of hepatitis A in many parts of the world. It is believed that the implications of these differences in the same region may have a deleterious effect, with an increasing number of susceptible adults, what creates the potential for epidemics ${ }^{16,10,17}$.

After multivariate analysis, ages from 11 to 14 years old were associated with greater prevalence of IgG anti-HAV, and it indicated a progressive increase in positivity with age. At 8 years old, $50 \%$ of students in this sample were immune, showing early exposure to hepatitis A. Several studies have shown that primary exposure to the virus increases with age ${ }^{16,18}$. The IgG anti-HAV seroprevalence curves according to age, especially in highly endemic regions, show that older people have more positivity for IgG anti-HAV, possibly because the probability of contact with the virus increases with the increase of time exposure. More recently, in studies conducted in developed countries and in developing ones, it has been observed later exposure to hepatitis A, due to the improvement of sanitary conditions in these regions ${ }^{19,12,18}$.

In this study there was a greater preva- 
Table 1 - Association between demographic and socio-economic conditions and the prevalence of IgG-antiVHA among schoolchildren in São Luis, MA, 2004

Tabela 1 - Associação entre as condições demográficas e socioeconômicas e a prevalência do antiVHA-lgG em escolares de São Luís-MA, 2004

\begin{tabular}{|c|c|c|c|c|c|}
\hline Variables & $\mathrm{n}$ & Positive n (\%) & PR (Gross) & $\begin{array}{l}\text { 95\% Confidence } \\
\text { Interval }\end{array}$ & $\begin{array}{l}\text { Value } \\
\text { of } P\end{array}$ \\
\hline Gender & & & & & 0.106 \\
\hline Female & 219 & $147(67)$ & 1.00 & & \\
\hline Male & 243 & $147(61)$ & 0.90 & $0.79-1.02$ & \\
\hline Age (years) & & & & & 0.038 \\
\hline 7-8 & 78 & $39(50)$ & 1.00 & & \\
\hline $9-10$ & 106 & $57(54)$ & 1.08 & $0.77-1.50$ & \\
\hline $11-12$ & 138 & $97(70)$ & 1.39 & $1.04-1.87$ & \\
\hline $13-14$ & 140 & $102(73)$ & 1.46 & $1.04-2.05$ & \\
\hline Number of household members & & & & & 0.630 \\
\hline$<4$ & 45 & $27(60)$ & 1.00 & & \\
\hline$\geq 4$ & 417 & $267(64)$ & 1.07 & $0.81-1.40$ & \\
\hline Numbers of rooms per house & & & & & 0.060 \\
\hline$<4$ & 240 & $164(68)$ & 1.00 & & \\
\hline$\geq 4$ & 222 & $130(59)$ & 0.86 & $0.73-1.01$ & \\
\hline Number or people per room & & & & & 0.004 \\
\hline 1 & 29 & $10(35)$ & 1.00 & & \\
\hline$>1$ & 433 & $284(66)$ & 1.90 & $1.28-2.83$ & \\
\hline Family income (minimum wages) & & & & & $<0.001$ \\
\hline$<1$ & 57 & $44(77)$ & 1.00 & & \\
\hline 1 & 205 & $152(74)$ & 0.96 & $0.78-1.18$ & \\
\hline 2 & 81 & $53(65)$ & 0.85 & $0.65-1.10$ & \\
\hline 3 & 31 & $20(65)$ & 0.84 & $0.62-1.12$ & \\
\hline 4 & 24 & $12(50)$ & 0.65 & $0.43-0.98$ & \\
\hline$>4$ & 64 & $13(20)$ & 0.26 & $0.17-0.42$ & \\
\hline Parents Education & & & & & $<0.001$ \\
\hline Illiterate & 20 & $18(90)$ & 1.00 & & \\
\hline Incomplete elementary school & 58 & $41(71)$ & 0.79 & $0.60-1.02$ & \\
\hline Complete elementary school & 176 & $137(78)$ & 0.86 & $0.74-1.02$ & \\
\hline Incomplete high school & 100 & $53(53)$ & 0.59 & $0.47-0.74$ & \\
\hline Complete high school & 56 & $36(64)$ & 0.71 & $0.57-0.90$ & \\
\hline Higher education & 52 & $9(17)$ & 0.19 & $0.11-0.34$ & \\
\hline Piped water supply & & & & & 0.002 \\
\hline Yes & 419 & $259(62)$ & 1.00 & & \\
\hline No & 43 & $35(81)$ & 1.32 & $1.11-1.56$ & \\
\hline Number of bathrooms per house & & & & & $<0.001$ \\
\hline$>=2$ & 103 & $36(35)$ & 1.00 & & \\
\hline$<2$ & 359 & $258(72)$ & 2.06 & $1.46-2.89$ & \\
\hline
\end{tabular}

RP: Prevalence Ratio [Razão de Prevalências] 
Table 2 - Multivariate analysis for socioeconomic conditions and the prevalence of IgG-antiVHA among schoolchildren in São Luís (MA), 2004

Tabela 2 - Análise multivariada para as condições socioeconômicas e a prevalência do antiVHA-lgG em escolares de São Luís (MA), 2004

\begin{tabular}{|c|c|c|c|}
\hline Variables & PR (Adjusted) & $\begin{array}{l}\text { 95\% Confidence } \\
\text { Interval }\end{array}$ & Value of $\mathrm{P}$ \\
\hline Age (years) & & & 0.017 \\
\hline $7-8$ & 1.00 & & \\
\hline $9-10$ & 1.05 & $0.78-1.42$ & \\
\hline $11-12$ & 1.36 & $1.03-1.80$ & \\
\hline $13-14$ & 1.40 & $1.03-1.89$ & \\
\hline Number or people per room & & & 0.013 \\
\hline 1 & 1.00 & & \\
\hline$>1$ & 1.55 & $1.11-2.18$ & \\
\hline Parents Education & & & $<0.001$ \\
\hline Illiterate & 1.00 & & \\
\hline Incomplete elementary school & 0.84 & $0.63-1.12$ & \\
\hline Complete elementary school & 0.91 & $0.76-1.09$ & \\
\hline Incomplete high school & 0.68 & $0.54-0.86$ & \\
\hline Complete high school & 0.80 & $0.63-1.03$ & \\
\hline Higher education & 0.26 & $0.15-0.46$ & \\
\hline Number of bathrooms per house & & & 0.031 \\
\hline$>=2$ & 1.00 & & \\
\hline$<2$ & 1.36 & $1.03-1.80$ & \\
\hline
\end{tabular}

RP: Prevalence Ratio [Razão de Prevalências]

lence of IgG anti-HAV among students who slept with more than one person in the room, which indicated that the agglomeration was probably an important risk factor associated with transmission of hepatitis A. Several reports have shown an association between this variable and the positivity of anti-HAV ${ }^{20,21}$.

The primary exposure to the virus increases as socioeconomic level decreases. Ninety percent of students with illiterate parents (the head of the family) and $76 \%$ of those whose parents had only elementary education tested positive for IgG anti-HAV, which may represent lack of knowledge about health and hygiene, important factors in preventing the transmission of diseases. It was also observed in the unadjusted analysis that students with lower family income had higher prevalence of IgG anti-HAV.
However the association between family income and prevalence of hepatitis A has disappeared in the multivariate analysis. These findings are supported by studies conducted in countries like Chile, Italy, Hong Kong, Shanghai and Brazil, where the educational level of parents was a protective factor for hepatitis $\mathrm{A}^{20,21,22,23,7,17}$.

The number of bathrooms per house is perhaps an indicator of hygiene and sanitary conditions. It is possible that the number of bathrooms is associated with certain hygiene habits, especially the habit of washing hands, which is known to be clearly related to the transmission of pathogens via the fecal-oral route. In this study, fewer bathrooms per house was associated with higher prevalence of hepatitis A. It's possible that this translates into fewer opportunities for hand washing and it is 
an indicator of more precarious hygienic conditions, especially in houses that do not have bathrooms inside.

It is important to note that the immunization program for hepatitis A in childhood has been proven effective in several countries including Argentina, Australia, Israel, Italy, Spain and China, and it has been able to drastically reduce the incidence of infection, outbreaks, mortality and hospitalization for hepatitis $\mathrm{A}^{24}$. The results found here lead us to speculate that, in the future, the number of susceptible individuals in adulthood must be high, especially those of higher socioeconomic status and students from private schools, who will be under constant risk of infection and may suffer more severe manifestations of the disease. This observation justifies the discussion of vaccination against hepatitis A in a universal way in Brazil, a fact emphasized recently by Vital et al. ${ }^{25}$.

A limitation of this study was the inclusion of a greater number of students aged between 11 and 14 years old than those aged from 7 to 10 years old in the sample, which may have led to an overestimation of the prevalence of hepatitis A among school children of São Luís since the prevalence of IgG anti-HAV infection increased with age. This fact occurred because fewer parents of children aged from 7 to 10 years signed a consent form to take part in the research.

In conclusion, the prevalence of IgG anti-HAV found in the students of São Luís was elevated and it was comparable to that one observed in other regions with similar socioeconomic and sanitary conditions. Higher prevalence of IgG anti-HAV was observed in the older students, those from 11 to 14 years old, from public schools, whose parents have low education levels, who sleep with more than one person per bedroom and who have less than two bathrooms in the house. The results suggest that raising the educational level of parents, reducing agglomeration and or increasing the number of bathrooms in a house are important actions for reducing transmission of hepatitis A virus and reducing its prevalence.

\section{Acknowledgements}

Our thanks to the Oswaldo Cruz Institute, in particular Genildo Cardoso (Health Department), Arild O. Lima (Biology Department of the Oswaldo Cruz Institute) and Antonio C. Fernandes Junior (Technical Director of the Oswaldo Cruz Institute LACEN-MA). Our sincere thanks to all the students, parents and principals of the schools that took part in this study.

\section{References}

1. Koff RS. Hepatitis A. Lancet 1998; 351: 1643-9.

2. Lemon SM. Inactivated hepatitis A virus vaccines. Hepatology 1992; 15: 194-7.

3. O'Grady J. Modern management of acute liver failure. Clin Liver Dis 2007; 11: 291-303.

4. Ferreira TC et al. Hepatitis A acute liver failure: followup of pediatric patients in southern Brazil. JVirol Hepat 2008; 15(S2): 66-8.

5. Ciocca M. Clinical course and consequences of hepatitis infection. Vaccine 2000; 18: S71-4.

6. Tanaka J. Hepatitis A shifting epidemiology in Latin America. Vaccine 2000; 18: 57-70.
7. Ximenes RAA et al. Multilevel analysis of hepatitis A infection in children adolescents: a household survey in the Northeast and Central-West region of Brazil. Int J Epidemiol 2008; 37: 852-61.

8. Queiróz DAO et al. Soroepidemiologia da infecção pelo vírus da hepatite A em meninos de rua de Goiânia Goiás. Rev Soc Brás Méd Tropic 1995; 28(3): 194-203.

9. Fiaccadore FS et al. Prevalence of hepatitis A infection in Goiânia, Goiás, Brazil, by molecular and serological procedures, 1995 - 2002. Mem Inst Oswaldo Cruz 2006; 4: 423-6.

10. Tapya-conyer R et al. Hepatitis A in Latin America: a changing epidemiologic pattern. Am J Trop Med Hyg 1999; 61: 825-9. 
11. Ferreira CT et al. Soroepidemiologia da hepatite A em dois grupos populacionais economicamente distintos de Porto Alegre. Gastro. Endosc Dig 1996; 15: 85-90.

12. Dinelli MIS et al. Anti-hepatitis A virus frequency in adolescents at an outpatient clinic in São Paulo, Brazil. Rev Inst Med Trop SP 2006; 1: 43-44.

13. Carrilho FJ, Mendes CC, Silva LC. Epidemiology of hepatitis A and E virus infection in Brazil. Gastroentrol. Hepatol 2005; 28: 118-25.

14. Instituto Brasileiro de Geografia e Estatística (IBGE). Indicadores sociais. População e domicílio: Censo Demográfico 2000. Disponível em http:/ / www.ibge.gov. br. [Acessado em 12 de outubro de 2004 e 28 de janeiro de 2009]

15. Secretaria de Educação Estadual e Municipal. Supervisão de Informática e Estatística. Relação das escolas que ministram Ensino Fundamental com matrícula inicial por idade e série, São Luís, 2002.

16. Shapiro CN, Margolis HS. Worldwide epidemiology of hepatitis A virus infection. J Hepatol 1993; 18: 11-4.

17. Zhi-yu X et al. Decline in the risk of hepatitis A virus infection in China, a country with booming economy and changing lifestyles. JViral Hepatitis 2008; 15: 33-7.

18. Vitral CL et al. Age-specific prevalence of antibodies to Hepatitis A in children and adolescents from Rio de Janeiro, Brazil, 1978 and 1995. Relationship of prevalence to environment factors. Mem Inst Oswaldo Cruz 1998; 93: 123-8.
19. Dal-ré R, Corceira PG, Garcia-de-Lomas J. A large percentage of the Spanish population under 30 years of age is not protected against Hepatitis A. J Med Virol 2000; 60: 363-6.

20. Stroffolini et al. Baseline soroepidemiology of hepatitis A virus infection among children and teenagers in Italy. Infection 1991; 19: 97-100.

21. Almeida LM et al. The Epidemiology of Hepatitis A in Rio de Janeiro: environmental and domestic risk factors. Epidemiol Infect 2001; 127: 327-33.

22. Lee A et al. Should adolescents be vaccinated against Hepatitis A: the Hong Kong experience. Vaccine 2000; 18: 941-6.

23. Fix AD et al. Age-specific prevalence of antibodies to Hepatitis A in Santiago, Chile: risk factors and shift in age of infection among children and young adults. Am J Trop Med Hyg 2002; 5: 628-32.

24. Hendricks $\mathrm{G}$ et al. Has the time come to control hepatitis A globally? Matching prevention to the changing epidemiology. J Viral Hepatitis 2008; 15: 1-15.

25. Vitral CL et al. Shifting epidemiology of hepatitis A in Brazil: should we think about immunization policy? $J$ Virol Hepat 2008; 15 (S2): 22-5.

Received: 27/04/2010

Final version: 04/09/2011

Approved: 17/10/2011 